\title{
An Input-output Analysis of Sources of Growth and Key Sectors
}

\author{
in Malaysia
}

\author{
Rohana bt Kamaruddin \\ Faculty of Business Management \\ Universiti Teknologi MARA, Malaysia \\ Tel: 60-3-5544-4935 E-mail: rohana070@salam.uitm.edu.my/rohana77@hotmail.com
}

Zakariah Abdul Rashid

Faculty of Economics and Management

Universiti Putra Malaysia, Malaysia

Tel: 60-3-8946-7702Ｅ-mail: zakariah@econ.upm.edu.my

\author{
Kamaruzaman Jusoff \\ Faculty of Forestry \\ Universiti Putra Malaysia \\ Serdang 43400 Selangor, Malaysia \\ Tel: 60-3-8946-7176Ｅ-mail: kamaruz@putra.upm.edu.my
}

\begin{abstract}
The paper examines the sources of growth and key sectors of Malaysia's economy over 1978-2000 using a decomposition method and Rasmussen degree of dispersion within the input-output (IO) framework. The model uses three comparable IO tables for 1978, 1991 and 2000 as the main data sources and accounts for output changes from a demand side perspective. The chosen structural decomposition analysis (SDA) based on the comparison between two IO tables, allows us to decompose each sector's and industry's output growth. It decomposes output growth of each sector to domestic demand expansion, export demand expansion, import substitution of final goods, import substitution of intermediate goods, and changes in IO coefficients. The analysis by sub periods, 1978-1991 and 1991-2000 show that there was a switch in the role of domestic-demand and export-demand expansion. The constituent factors that contribute positively to change in the period, 1978-1991 are mostly domestic demand expansion (63.35\%) and export demand expansion (33.33\%). However in the second sub period, 1991-2000, export demand expansion increased by $12.43 \%$ and domestic demand expansion decreased to $48.11 \%$. Taking the whole 1978-2000, domestic demand expansion appears to have been the major source of output growth, contributing about $82 \%$, followed by export demand expansion $62 \%$. Combining the source of growth and key sector through backward linkages, the study revealed that most of the sectors induced its supplying production strongly for domestic market.
\end{abstract}

Keywords: Structural change, Input-output, Decomposition, Domestic demand expansion, Export demand expansion,

Linkages

\section{Introduction}

The Malaysian economy has experienced rapid economic growth during the past few decades. Malaysia's GDP grew at an average rate of 5.1 percent in the 1960's and 7.8 percent in the 1970s. In the 1980's, the Malaysian economy continued to grow, albeit at a lower average rate of 0.05 percent due to the global recession in $1985-1986$. With the recovery of the world economy, the Malaysian economy picked up rather rapidly from 1991 to 1995 at an average rate of 9.5 percent per annum. The Malaysian GDP expanded at the average rate of 8.7 percent per annum during the period 1996 - 1997 before registering a negative growth rate of 7.4 percent in 1998 due to the East Asian financial crisis. Efforts by the government to resuscitate the economy starting from the mid 1998 succeeded in generating an average growth rate of 4.75 percent during the period from $1999-2002$. The experience of the rapid economic growth has been accompanied by low consumer price index, low unemployment and rising per capita income. 
A basic development fact is that countries experienced a structural transformation as they develop. This unprecedented rapid economic growth has been accompanied by a marked structural transformation of the Malaysian economy. While the agriculture sector's share in GDP declined from 22.3 percent in 1980 to 8.7 percent in 2002, the contribution of the industrial sector grew from 38.5 percent in 1980 to 44.5 percent in 2002. Most of this surge came from an expanding manufacturing sector, with its contribution to the GDP increasing by 50 percent over two decades from 18.5 percent in 1980 to 29.9 percent in 2002 .

The manufacturing sector led in contributing to the buoyant growth of the economy with expansion of output in most industries, brought about by the strong demand in both the domestic and export market.

\section{Methodology}

\subsection{Structural decomposition analysis}

This study deals with the composition structural change of relevant economic sectors or industries, within the general approach developed by Chenery (1960) and extended by Syrquin (1988) and Syrquin and Chenery (1989). A considerable number of recent applications of the method exist in the literature (e.g., Dewhurst, 1994; Liu and Sal, 1999). According to Rose and Miernyk (1989), structural decomposition analysis can be defined as a method of distinguishing major changes within an economy by means of comparative static changes in key sets of parameters. Its origins date back to the work of Leontief (1941) on the structure of the United States economy. Structural decomposition analysis (SDA) is a comparative static method to assess the structural changes in an economy using input-output data. Based on the idea that the change over time on some variable is decomposed into the changes in its determinants, it is widely used as a tool to quantify the underlying sources of change.

The I-O model is widely used in the study of economic structural changes for several reasons. First, an I-O table provides a comprehensive and consistent statistical account of an economy by taking into account the most important economic transactions (or direct input coefficients), which generally cannot be obtained from a national statistical book in most countries, especially in developing ones. Second, an I-O table explicitly accounts for the interdependence of different economic activities by incorporating the size and composition of the various industries' mutual input demands (measured by interdependent coefficients or the Leontief inverse), which enable us to incorporate both direct and indirect industrial interrelations into the analysis. Third, as the comparison takes two or more snapshots of the economy at different moments to analyze the changes over a period of time, it exploits most of the advantages of the IO framework and avoids the static nature of the method. Finally, the fourth, within the IO framework, it is possible to decompose the structure changes into different components, such as final demand, import substitution, export expansion, and technological change (Liu and Saal, 1999).

\subsection{Analytical framework}

The methodology used in this study is based on the contribution of Albala-Bertrand (1999), where the changes in output can be decomposed to final demand expansion (FDE), export demand expansion (EDE), import substitution of final goods (ISF), import substitution of intermediate goods (ISW) and changes in technical coefficients (IOCs). Let us assume that we have available IO accounting matrices for a given economy for at least two years, i.e. a base year 0 and a comparison year 1 . An IO accounting framework shows how the gross output of each industry is distributed among the corresponding demands.

$$
X=W_{i}+F+E-M
$$

Where $\mathrm{X}, \mathrm{W}, \mathrm{F}, \mathrm{E}$ and $\mathrm{M}$ are respectively vectors of gross output, matrix of intermediated demand, matrix of domestic final demand, matrix of foreign demand, and matrix of intermediate and final imports.

Let $\mathrm{a}_{\mathrm{ij}}$ represent the unit-input requirement of the jth industry for the output of the ith industry in terms of standard technical coefficients; $\mathrm{a}_{\mathrm{ij}}=\mathrm{W}_{\mathrm{ij}} / \mathrm{X}_{\mathrm{j}}$. Therefore, this generates an $\mathrm{n} \mathrm{x} \mathrm{n}$ matrix A of coefficients or, rearranging, we have

$$
A X=W
$$

Substituting equation ( 2) into equation ( 1), we obtain

$$
X=A X+F+E-M
$$

Let us assume that, at the level of each industry, imports are demanded for intermediate inputs and for final use in fixed proportions $\hat{M} \mathrm{w}$ and $\hat{M} \mathrm{~F}$ respectively. Then, we have

$$
M=\hat{M}^{W} A X+\hat{M} F^{F}
$$

where the symbol $\wedge$ indicates a diagonal matrix. Then, substituting equation (4) into equation (3), we have

$$
X=\left(I-\hat{M}^{W}\right) A X+\left(I-\hat{M}^{F}\right)+E
$$


Let $\hat{U^{W}}=\left(I-\hat{M}^{w}\right)$ and $\hat{U^{F}}=\left(I-\hat{M}^{F}\right)$. Notice that these two matrices give the ratios of domestic-to-total-intermediate demands and domestic-to-total-final demands respectively. As such, they are indicators of import substitution. Using these expressions, equation (5) becomes

$$
X=\hat{U} A X+\hat{U}^{F}+E
$$

Therefore, solving for $\mathrm{X}$, we obtain the IO model

$$
X=(I-\hat{U} A)^{-1}\left(\stackrel{F}{U^{F}}+E\right)
$$

Notice that the first term on the right-hand side is the Leontief inverse for domestic intermediates only, and represents coefficients or weights, while the second term contains both domestic and foreign final demands, and represents volumes. In order to use less notation, let $D^{-1}=\left(I-\hat{U^{W}} A\right)^{-1}$ and let $G=\left(\hat{U^{F}}+E\right)$. Then the IO system becomes

$$
X=D^{-1} G
$$

\subsubsection{Decomposition of output change}

The decomposition of output change, i.e. absolute growth and the growth rate, between two periods amounts to calculating the first difference of equation (8). We have

$$
\Delta X=\Delta\left(D^{-1} G\right)=D_{0}^{-1} \Delta G+\Delta D^{-1} G_{0}+\Delta D^{-1} \Delta G
$$

Using either the Paasche and Laspeyres index weighting respectively by taking the first or the second term on the right-hand side can absorb the third term., i.e.

$$
\begin{gathered}
\Delta X=D_{1}^{-1} \Delta G+\Delta D^{-1} G_{0} \\
\Delta X=D_{0}^{-1} \Delta G+\Delta D^{-1} G_{1}
\end{gathered}
$$

The numerical results from the two alternative weightings are not normally equivalent and can be very different if the interaction term is large. A simpler method that distributes the interactive term proportionally in the other two terms is to take the simple arithmetical average of the Paasche and Laspeyres weighting results.

$$
D_{0}^{-1} \Delta G=D_{0}^{-1}\left(\hat{U_{0}^{F}} \Delta F+\Delta E+\Delta \hat{U^{F}} F_{I}\right)
$$

and

$$
\Delta D^{-1} G_{1}=D_{0}^{-1}\left(\Delta \hat{U} W_{1} i+\hat{U_{0}^{w}} \Delta A X_{1}\right.
$$

Therefore, letting $B_{0}=D_{0}^{-1}$, to carry less notation, the total decomposition for the absolute growth or variation in gross output will be

$$
\Delta X=B_{0} \hat{U}_{0}^{F} \Delta F+B_{0} \Delta E+B_{0} \Delta \hat{U}^{F} F_{1}+B_{0} \Delta \hat{U}^{W} W_{1} i+B_{0} \hat{U} \Delta A X_{1}
$$

The decomposition for the gross output growth rate can be obtained by dividing equation (14) element-wise by $\mathrm{X}_{0}$. Each of the five terms on the right-hand side of equation (14), in variation or growth terms, represents a direct and indirect contribution to the total demand for the gross output of the economy. The terms have the following standard meanings:

$$
\begin{array}{ll}
B_{0} \hat{U}_{0}^{F} \Delta F & \text { contribution of domestic demand expansion (FDE); } \\
B_{0} \Delta E & \text { contribution of export demand (EDE); } \\
B_{0} \Delta \hat{U} F_{1} & \text { contribution of import substitution of final goods (ISF); } \\
B_{0} \Delta \hat{U}^{F} F_{1} & \text { contribution of import substitution of intermediate goods(ISW); } \\
B_{0} \hat{U}_{0} \Delta A X_{1} & \text { contribution of changes in IO coefficients (IOCs). }
\end{array}
$$

\subsubsection{Decomposition of output share changes}

The share change for the ith industry is simply the difference between the gross output shares of the terminal year $\left(\mathrm{S}_{\mathrm{i} 1}\right)$ minus that of the base year $\left(\mathrm{S}_{\mathrm{i} 0}\right)$, i.e.

$\Delta \mathrm{Si} \quad=\mathrm{S}_{\mathrm{it}} \quad-\mathrm{S}_{\mathrm{t} 0}=\mathrm{X}_{\mathrm{i} 1} / \mathrm{X}_{\mathrm{t} 1}-\mathrm{X}_{\mathrm{i} 0} / \mathrm{X}_{\mathrm{t} 0}$ 
where $\mathrm{i}=1, \ldots, \mathrm{n}$ and $\mathrm{t}$ denotes the total. Let us first define

$\mathrm{X}_{\mathrm{i} 1}=\mathrm{X}_{\mathrm{i} 0}\left(1+\mathrm{g}_{\mathrm{i}}\right)^{\mathrm{n}}, \mathrm{X}_{\mathrm{t} 1}=\mathrm{X}_{\mathrm{t} 0}\left(1+\mathrm{g}_{\mathrm{a}}\right)^{\mathrm{n}}$

where $g_{i}$ and $g_{a}$ denote the gross output compounded growth rate for the ith industry and the economy's average gross output growth rate respectively. Replacing $\mathrm{X}_{\mathrm{i} 0}$ with

$\mathrm{X}_{\mathrm{to}} /\left(1+\mathrm{g}_{\mathrm{a}}\right)$ in equation (15) and manipulating yields

$\Delta \mathrm{Si}=\left[\mathrm{X}_{\mathrm{t} 1}-\left(1+\mathrm{g}_{\mathrm{a}}\right] / \mathrm{X}_{\mathrm{t} 1}\right.$

Alternatively, letting $\delta \quad \mathrm{X}_{\mathrm{i}}=\left[\mathrm{X}_{\mathrm{i} 1}-\left(1+\mathrm{g}_{\mathrm{a}}\right) \mathrm{X}_{\mathrm{i} 0}\right]$ leads to

$\Delta \mathrm{Si}=\delta \mathrm{X}_{\mathrm{i}} / \mathrm{X}_{\mathrm{t} 1}$

The numerator $\delta \mathrm{X}_{\mathrm{i}}$ contains the difference between the actual value of $\mathrm{X}_{\mathrm{i}}$ in the terminal year and the value of $\mathrm{X}_{\mathrm{i}}$ that would have occurred had it grown at the economy's average growth rate over the period. Therefore, the equation represents the deviation of each industry's gross output from balanced growth, normalized by the actual value of the gross output in the terminal year. This allows us to derive the decomposition formula in a closely analogous way to equation (11).

In matrix form, the case of Laspeyres weighting yields

$$
\delta X=D_{0}^{-1} \delta G+\Delta D^{-1} G_{1}
$$

By using the Laspeyres derivation. Therefore, applying the same solving procedure as before, and replacing $D_{0}^{-1}$ with $\mathrm{B}_{0}$, we obtain

$$
\delta X=B_{0} \hat{U}_{0}^{F} \delta F+B_{0} \delta E+B_{0} \Delta \hat{U}^{F} F_{1}+B_{0} \Delta \hat{U}^{W} W_{1} i+B_{0} \hat{U}_{0}^{w} \Delta A X_{1}
$$

Notice that the last three terms on the right-hand side are the same as before. Dividing equation (20) by $\mathrm{X}_{\mathrm{t}}$, we are back to equation (18), but in matrix form. The meanings of the terms are analogous to those for equation (14), but refer to the absolute value of the share change $(\delta \mathrm{X})$ and the relative share change $(\delta \mathrm{X} / \mathrm{X}$ i1), rather than the absolute growth $(\Delta \mathrm{X})$ and the growth rate $\left(\hat{X}^{-1} \Delta \mathrm{X}\right)$.

\subsubsection{Linkages Analysis in Terms of Production}

The expansion of manufacturing industry not only generates demand for its input, but also induces the expansion of industries, which use the commodities produced as inputs. The connection with supplier industries is called backward linkage while with that of purchasing industries is forward linkage. Together, both these linkages can be termed as technological linkages (Mohd Shahwahid, 1992). The backward linkages or input provision or derived demand is defined as an activity, which employs significant amount of intermediate inputs from other activities for production. The output utilization or forward linkages on the other hand, is defined as an activity that caters for final demand but also induces attempts to utilize its outputs as inputs in other new activities (Hirschman, 1958 \& Linnemann, 1987)

In the case of backward linkage effect, Rasmussen (1956) defined the power of dispersion (or measure of dispersion), which "describes the relative extent to which an increase in final demand for the products of industry $\mathrm{j}$ is dispersed throughout the system of industries". The power o dispersion of sector $\mathrm{j}$ is composed of unweighted sum of elements of column $\mathrm{j}$ divided by the number of sectors and standardized by the average of all elements of the inverse matrix (Linnemann, 1987).

The direct and indirect backward linkage index (or measures of dispersion) becomes,

$$
P_{j}=\frac{\frac{1}{n} \sum_{i-1}^{n} r_{i j}}{\frac{1}{n^{2}} \sum_{i=1}^{n} \sum_{j=1}^{n} r_{i j}}
$$

The numerator of the ratio $P_{j}$ denotes the average increase in output of a sector induced by a unit increase of the final demand for products of sector $\mathrm{j}$. In making international comparisons of sectoral linkages patterns, the average degree of sectoral interdependence for the whole economy when final demands increase by unity, must be considered, hence, standardizing $\mathrm{P}_{\mathrm{j}}$ by the average $\mathrm{r}_{\mathrm{ij}}$ in the denominator ( Bulmer-Thomas, 1982; Linnemann, 1987).

The value of the power of dispersion for an imaginary sector that equals exactly the average value of backward linkages in an economy is 1 . Consequently, if $P_{\mathrm{j}}$ is greater than 1 , it implies that sector $\mathrm{j}$

has the above-average backward linkage effects, whereas if $P_{j}$ is less than 1 , it can be stated that the sector $\mathrm{j}$ is operating in relative isolation from other sectors (Linnemann,1987). 
A dispersion measure for forward linkages, $\mathrm{P}_{\mathrm{j}}$ (equation 22), is based on the sum of row elements, $\mathrm{r}_{\mathrm{ij}}$, and is denoted by Rasmussen (1956) as the sensitivity of dispersion (Linnemann, 1987). Hirschman (1958) interpreted as high $\mathrm{P}_{\mathrm{i}}$ (greater than 1) as the particular sector I has to increase its output more than other sectors for each unit increase in final demand.

$$
P_{i}=\frac{\frac{1}{n} \sum_{j=1}^{n} r_{i j}}{\frac{1}{n^{2}} \sum_{i=1}^{n} \sum_{j=1}^{n} r_{i j}}
$$

High forward linkages occur when a sector's output is or could be used by many others as an input; by expanding capacity in such a sector, "inducement" are provided to using industries which now have an incentives to expand output to take advantage of the increased availability of inputs (Bulmer-Thomas, 1982).

The numerator in equation (22) refers to the ith row sum of Leontif inverse, which in turn measures the total impact on the sector, $i$ when the final demand for all sectors increased by unity. If the impact is large, it suggests that increased investment in sector would induced output increases in all using sectors, as users take advantage of the increased availability of inputs. Basically, the indices in equation (21) and (22) are based on the method of averaging.

\subsection{Data}

Basically, the present study uses secondary data from Malaysia's input-output tables published by the Department of Statistics. The following three tables represent two period of Malaysia Plan, half term of OPP1 (1978-1990) and OPP2 (1991-2000), including the latest one.

1. Input-Output Table, 1978 (Malaysia, Department of Statistics 1982)

2. Input-Output Table, 1991 (Malaysia, Department of Statistics 2000)

3. Input-Output Table, 2000 (Malaysia, Department of Statistics 2005)

In order to reveal the real changes in the variables, the nominal 1991 and 2000 input-output tables have been transformed into 1978 constant prices, making all the tables comparable. We use the producer price indices and import indices provided by the Department of Statistics.

\section{Results and discussion}

\subsection{Extent and constituents of change}

Table 1 compares the extent of structural shift in the two sub periods, if any, by determining the major sources of growth and the sectors contributing to the growth. At this level of aggregation, structural change was more significant in the 1991-2000 than in 1978 - 1991 periods(Note 1). There was a significant fall in the share of the agriculture and a significant increase in that of the service sector over the whole 1978-2000 periods. Also, the most notable improvement in the share of the manufacturing sector was achieved in the period, 1991-2000.

[Table 1]

A comparison of the two subperiods shows that there was a switch in the role of domestic demand expansion, export demand expansion, imports substitution of final goods and technology. The constituent factors that contribute positively changes in the period, 1978-1991 are mostly domestic demand expansion (63.35\%), export demand expansion (33.30\%) and technical change (18.18\%). However in the second sub period 1991-2000, export demand expansion increased by $12.43 \%$ and domestic demand expansion decreased to $48.11 \%$. The import substitution of final goods contributed positively to the economy by $9.73 \%$ compare to $-10.76 \%$ in 1978 to 1991 period. However the technical change has decreased from $18.18 \%$ in 1978-1991 to $9.26 \%$ in 1991-2000. In both sub periods, import substitution of intermediate goods contributes negatively to the economy. Taking the whole 1978-2000 period, domestic demand expansion appears to have been the major source of output growth, contributing about $82 \%$, followed by export demand expansion (62\%). Generally, the result of the analysis shows that as output grew during the whole period was driven by domestic demand expansion and technological change was less significant. In the first sub period, the greater part of output growth came from the service and the manufacturing (light and heavy industries) sectors, which together contributed about $90 \%$ of the economy's output growth, while the agriculture contributed less than $7 \%$. The second sub period saw a clear shift in sectoral contribution to output growth, with the heavy industries being the major contributing source of output growth, about $67 \%$ and services about $37 \%$. The contribution of light industry declined to about $10 \%$ and mining sectors have increase about $5 \%$.

The aggregated results hide the heterogeneous nature of the structural change, so the rest of the section presented a more disaggregated view, and concentrates mostly on the two sub periods; 1991-2000 (OPP2) and 1978-1991 (OPP1). Table 2 present the growth rates for each of the two periods respectively. The aggregated results hide the heterogeneous nature of the structural change, so the rest of the section presented a more disaggregated view, and concentrates mostly on the two sub periods; 1991-2000 (OPP2) and 1978-1991 (OPP1). Tables 2 and Table 3 present the growth rates and 
share change for each of the two periods respectively. The first column of Table $5\left(\Delta \mathrm{X} / \mathrm{X}_{\mathrm{t} 1}\right)$ is the growth rate in gross output, expressed in percentage points for each sector, while the first column of Table 6 is the share change of gross output. The other five columns (FDE, EDE, ISF, ISW and IOC) show the way in which growth rates (Table 2) and share variations (Table 3) are disaggregated in terms of demand sources. These sources should sum to the values in the first column. The last column $\left(\mathrm{S}_{1978}\right.$ or $\left.\mathrm{S}_{2000}\right)$ expresses the share of each sector in the total output, in the initial year.

[Table 2]

[Table 3]

\subsubsection{Sub period: $1978-1991$}

Domestic demand expansion and export demand expansion had a relatively strong effect on the economy's gross output growth rate (Table 2), particularly in the heavy industry, light industry, agriculture, services and mining. The industries that were most driven by the domestic and export expansion is electrical machinery, non-electrical machinery and industrial chemical. However the share of domestic and export expansion to the gross output decreased in the overall heavy industries but increased in the sub sectors of electrical machinery and industrial chemical. In the light industries, most of the sub sectors showed positive gross output growth rates. During the period there is evidence of the effects of technological change on output growth occurring in agriculture, light industry, heavy industry and services.

\subsubsection{Agriculture and mining sectors.}

This sector was domestic-oriented, as domestic expansion contributed about 1065 percent to total sectoral output. Export expansion contributed about 623 percent technical change 827 percent. The sector contributed about 2173 percent to the total output growth of the economy.

Within the broad agriculture sector, mainly; other agriculture, rubber, oil palm, livestock, forestry and fishing subsectors have positive growth rate and positive change in gross output share in the domestic and export expansion. Import substitution of final and intermediate output shows a negative contribution to both growth rate (-208.77 and -132.33) (Table 2) and output share (-64.41 and -38.31) (Table3) which indicates that in the agriculture sector, Malaysia still relies on imported commodities to generate growth in this sector. The period saw the effects of technical change on output growth occurring both in growth rate ( 827 percent) and share changes (134 percent) which indicate there are linkages in this sector.

Domestic demand expansion contributed about 51 percent to this sector's output growth. In terms of growth rate, mining was found to contribute considerably about 227.16 percent in domestic demand expansion and 186.06 in export expansion. However in terms of change in gross output, the share was lower at 30.68 in domestic demand expansion and 35.08 in export demand expansion. Overall the sector only contributed about 351 percent to total output growth of the economy with a negative technical change.

\subsubsection{Manufacturing sector.}

\subsection{Light and heavy industry sectors}

Like the agriculture sector, the light industry sector was found to be domestic-oriented during the first sub period. Export expansion accounted about 4904 percent, and the export demand expansion about for 3396 percent of the light industry sectoral output growth. Within the sector there were twelve domestic-driven sub sectors, namely diary product, vegetable fruit, grain mill, baker confectionary, other foods, animal feed, beverages, tobacco, textiles, wearing, sawmills, furniture fixture and paper printing; and two export-driven sub sectors, namely oils and fats and furniture fixture.

This sector was found to be domestic-oriented in the sub period. Domestic demand expansion contributed about 12242 percent to its output growth while the industry itself contributed considerably about 18189 percent to the overall output growth of the economy. Two sub sectors were export-driven and are industrial chemical and electrical machinery. Twelve were domestic-driven sub sectors; namely paints \& lacquers, other chemical product, petroleum \& coal product, rubber product, plastic product, glass product, cement, non-metallic, basic metal, other metal and non electrical machinery. Overall, the heavy industry shows a positive growth rate during the sub periods, however its share declines in the sub sectors namely, paints \& lacquers, petroleum \& coal product, rubber product, glass product, non metallic, non-electrical machinery and other manufacture products for export and demand expansion. However, the import substitution for intermediate goods and final demand gain in gross output share as the export and domestic demand decline.

\subsubsection{Services sector}

The sector was found to be domestically driven, as domestic demand expansion contributed about 979 percent to the sector's output growth. The service sector contributed 921 percent to the overall output growth of the economy. This study did not show the disaggregate sector of services, however its share of contribution to economy was high (42 percent). 


\subsubsection{Second sub period: $1991-2000$}

Like the first sub period, the second sub period witnessed output growth dominated by the effects of domestic demand expansion, which contributed about 48 percent to the overall growth of the economy. Export demand expansion, on the other hand, contributed 46 percent, 2 percent less than the domestic demand. The second sub period witnessed a fall in the effects of technical change on output growth, from 18 percent in the first sub period to 9 percent in the second sub period (Table 4).

[Table 4]

\subsubsection{Agriculture and mining sectors}

As in the first sub period, domestic expansion was also the major source of growth in the agriculture sector during the second sub period, contributing about 234 percent of its growth, while export expansion 85 percent and 70 percent was driven by import substitution of final goods and 217 percent due to the technical change in the sectoral output. The gross output growth rate was positive for all the sub sectors except for oil palm sector, which has a negative rate for, export expansion, domestic and import substitution for final and intermediate goods. However, the change in gross output share was negative for domestic demand expansion and positive for export demand expansion and import substitution in intermediate goods in the sub sector forestry, which implies that most of timber is being exported and are the substitute for intermediate goods.

Unlike in the first sub period, the mining sector becomes export-oriented in the second sub period. Export expansion contributed 284 percent, while import substitution for final goods accounted for 43 percent of the output growth. There was negative effect of technological change on mining output growth. The sector contributed about 378 percent, an increase of about 28 percent from the first sub period.

\subsubsection{Manufacturing sector}

\subsection{Light and heavy industry sectors}

Unlike the first sub period, the light industry saw a decline in contribution of the domestic demand expansion from 4904 percent in 1978-1991 to 1687 percent in 1991-2000 and export demand expansion from of 1760 percent to output growth. Import substitution of final goods, which contributed negative growth to output in first sub period, has a positive contribution of 353 percent in the second sub period. The sector contribution declined to almost one quarter to the overall output growth compare with the first sub period. In terms of gross output growth rate most of sub sectors contribute positively in the domestic and export expansion to the economy, except oils and fat. However share of sub sectors, dairy product, vegetable fruit, oil and fats, baker confectionary, textiles, wearing, sawmills in gross output declined.

The sector's contribution to overall output growth increased to 67 percent, which took up the share lost by the light industry sector. Export expansion contributed substantially to the gross output growth accounting for 3324 percent, import substitution for final goods 543 percent and domestic demand expansion 2855 percent. Thirteen sub sectors, namely, industrial chemical, paints and lacquers, other chemical product, rubber product, processed rubber, plastic product, glass product, non metallic, basic metal, other metal, non electrical, electrical machinery, other transport and other manufacturing product were found to be export-oriented. The petroleum and coal product, cement and non-metallic were driven by domestic demand expansion. All the sub sectors are driven by import substitution for final goods.

\subsubsection{Service sector}

Like the first sub period, the services sector is still dominated by domestic demand expansion but its contribution declined to 43 percent. However the sector contributed about 350 percent to the overall output growth of the economy, a decline compared to the first sub period.

To sum up, all the major sectors of heavy industries were export oriented during the period 1991-2000, the gross output growth rate was 8128 percent, which is four times higher than light industry. So we can conclude that the Malaysia economy become heavy oriented industrialization during the Second OPP.

\subsubsection{Overall Period: 1978-2000}

In the overall period, the whole economy appeared to be influenced by domestic demand expansion and export demand expansion. About 82 percent of the economy's overall growth was due to domestic driven, and 61 percent due to export-driven accounted, while technical change and import substitution had negative contribution at -21.72 percent and -18.6 percent respectively. (Table 4 )

[Table 4]

$\square$ Agriculture sector. The sector was found to be domestic -oriented during the whole period. Domestic demand expansion contributed considerably to the sectoral growth (2471 percent), while export expansion contributed 
1152 percent and technical change had contribution of -692 percent. Gross output growth rates for all the sub sectors, namely; other agriculture, livestock, forestry, fishing show a positive growth but rubber plantation, and oil palm show a decline in growth to the economy. The growth rate of domestic and export expansion is positive but its share in gross output declines for all the sub sectors. There is gain in share for import substitution for intermediate and final goods.

- Mining Sector. From the output growth rate the sector was found to be slightly higher in its export expansion (1333 percent) than its domestic expansion (1299 percent) but the output share decreased to -3 percent for domestic and -2.84 percent for export expansion. The import substitution for intermediate output share increased to 10.17 percent. The sector contributed about 8.5 percent to the overall output growth of the economy.

- Manufacturing sector- Light and heavy industry sectors: The sector was found to be driven by domestic demand expansion for the overall period. About 19860 percent of sectoral growth was due to domestic demand expansion, while export expansion accounted for 16272 percent. The sector contributed about 28263 percent to the overall growth of the economy. In the gross output growth rate all the sub sectors in the light industry experienced a positive growth rate for export and domestic expansion, but in terms of gross output share, the share of sub sectors, namely; vegetable fruit, oils and fats, baker confectionery, other foods, animal feed, furniture fixture and paper printing showed a decline. As in the second sub period, this sector was export-oriented driven during the overall period, which contributed about 61 percent to the sector's growth. The sector contributed 61 percent to the overall growth of the economy. All the sub sectors showed a positive growth rate in the export and domestic side, and only a few sub sectors made gain in their output share, namely, rubber product, plastic product and electrical machinery. There were fourteen sub sectors that had negative output share in domestic and export expansion but gain in share of import substitution of intermediate and final goods. These include; industrial chemical, paints and lacquers, other chemical product, petroleum and coal product, processed rubber, glass product, cement, non metallic, basic metal, other metal, non electrical machinery, motor vehicles, other transport and other manufacture products.

$\square$ Services sector. This sector was domestically driven during the overall period. About expansion, while the sector's contribution to the overall growth of the economy was about 20 percent. In sum, agriculture, light industry and services were found to be domestic oriented in the 1978-2000, while the mining and heavy industry were export-oriented with a very slight increase. The heavy industry sector was found to be the leading sector in terms of contribution to the overall growth of the economy during the overall period.

\subsection{Analysis of linkages effect}

The results of both backward and forward linkages in terms of output are presented in Appendix 3. After estimation of the linkages, the next step was to rank the sectors. A ranking was done to both backward and forward linkages. Ranking provides a basis for assigning priorities to different sectors in the economy, from the viewpoint of development strategy. Thus, the procedure allowed the sectors to be ranked in the descending order of priority in terms of their potential linkage generation.

A key sector is defined as a sector in which both strong backward and forward linkages are greater than unity. In fact, both backward and forward linkages are two different sides of the same coin, namely a forward linkage of one sector being regarded as a backward linkage of another. But in practice, it is important to know which sector is a catalyst for developing linkages. In this regard, backward linkage likely to be more important since it represents the demand of inputs from other sectors necessitated by productive activity of one sector. Table 3 presents the result of backward linkages in order to determine the key sectors in the Malaysian economy. The key sectors that show a high backward linkage in the year 1978,1991 and 2000 are from the livestock (agriculture), two sectors from light industry (grain mill and rubber product) and one sector from heavy industry (basic metal product).

For the year 1978, 19 sectors show high backward linkages, with the light industry dominating the importance on the supply side production ( 10 sectors) and follow by heavy industry ( 8 sectors) and one sector from agriculture. In the year 1991, 18 sectors contributed as key sectors in the economy, with 9 sectors from heavy industry, 8 sectors from light industry and one from agriculture. However, the result of key sector in 2000 show that the contribution from agriculture come from 4 sectors; namely others agriculture, rubber plantation, oil palm and livestock with a higher backward linkages, 7 sectors from the heavy industry and 4 sectors from the light industry.

From the result above, we can conclude that the evolution of intersectoral linkages at different stages of industrialization is important because the nature and extent of intersectoral linkages affect not only the overall growth rate, but also determine the structural balance and international competitiveness of the economy. Hence, in the next analysis, Table 4 presents the link between the sources of growth and the key sectors for the year 2000, in order to look at the relationship. 


\section{Conclusion and recommendation}

The study found that the Malaysian economy had undergone a number of structural changes, caused mainly by the re-orientation of industrialization strategies as well as by variations in the composition of domestic demand. In the period 1978-1991, input-output technique was able to capture the 13 years scenario of the country direction during the second half of OPP1. During this period 1978-1991, the result of the analysis indicates that domestic -demand expansion was the dominant source of growth in the economy especially in the mining and service sectors. However if the comparison would be made between domestic expansion and export expansion in agriculture, light industry and heavy industry, domestic demand expansion is still dominating in all these sectors. In the second OPP2, 1991-2000, the growth in mining and heavy industry were due mainly to export expansion. Surprisingly, the light industry experienced a negative growth during this sub period, while agriculture and services showed a declining growth trend. The decline in the light industry probably due to the Malaysia economic recession in 1987, and government policy focus in heavy industry. During the overall period 1978-2000, the export expansion also appeared to be the dominant source of growth for heavy industry and mining, slightly higher in percentage than the domestic demand expansion. However, the other major sectors of like agriculture, light industry and services appeared to be dominated by domestic demand expansion. It can be concluded that the causes of structural changes in Malaysian economy, using input-output decomposition analysis technique is driven by shifts in final demand - mainly by consumption, trade and changes in the inter-industry relations arising from good linkages.

The changes in manufacturing export structure reflect that the Malaysian government's success in providing conducive settings at the macro level for an export-led industrial reorientation. These environments are shaped by such factors as human capital formation; export promotion measures, market friendly policies, political stability, good macro management and lastly the welfare of the population in general. As Malaysia economic success lies in the performance of the manufacturing sector, the realization of "Vision 2020" depends on the extent to which sector remains strong and can contribute to the economic growth. Lastly, the study has combined the source of growth and key sector through backward linkages; the study revealed that most of the key sectors induced its supplying production strongly for domestic demand expansion and export demand expansion; however leakages still exist in the economy.

\section{References}

Albala-Betrand, J. (1999). Structural Change in Chile: 1960-199: Economic System Research, Vol. 11, No. 3: 301-319

Bulmer-Thomas, V. (1982). Input-Output Analysis in Developing Countries: Sources, Methods and Application. John Wiley \& Sons Ltd, USA. 297p

Chenery, H. B., (1960). Patterns of Industrial Growth, American Economic Review, Vol. 50. No. 3, pp. 624 - 54

Dewhurst, J.H. (1994). Decomposition of Changes in Input-Output Tables: Economic System Research, 5 (1): 41-53

Hirschman, A.O. (1958). The Strategy of Economic Development. Yale University Press, New Haven, 217p.

Leontief, Wassily W. (1941). The Structure of American Economy. 1919 -1929: An Empirical Application of Equilibrium Analysis. Ist ed. Cambridge, Mass.: Harvard University Press

Linnemann, H. (1987). Export-Oriented Industrialization in Developing Countries. Council of Asian Manpower Studies, Manila. Singapore University Press.

Liu and Saal (1999). An Input Output Analysis of Structural Change in Apartheid Era South Africa: 1975-1993. Aston University. Birmingham. UK.

Malaysia, Department of Statistics. (1982). Input-Output Table, 1991. Kuala Lumpur.

Malaysia, Department of Statistics. (2000). Input-Output Table 2000. Kuala Lumpur.

Malaysia Standard Industrial Classification (2005), Department of Statistics, Kuala Lumpur

Mohd. Shahwahid Othman. (1992). Economic Impact of Malaysian Timber Exports. Journal of Tropical Science. 5 (1): $51-67$

Syrquin, M. (1988). Patterns of Structural Change. In Chenery, H. \& T.N. Srinivasan (eds) Handbook of Development Economics. Vol.1. Elvisier Science Publishers, 1988.

Syrquin, M. and Chenery, H. (1989). Three Decades of Industrialization. The World Bank Economic Review, Vol. 3, No. 2, pp. $145-181$

Note 1.

This statement comes from the application of an index of structural change (ISC) to the annualized (40-industry aggregation) share changes of each period. Indices of this nature are summary measures of variability, such as standard 
deviation. We use the formula. ISC $=\sum_{t}\left|\mathrm{~S}_{\mathrm{t} 1}-\mathrm{S}_{\mathrm{t} 0} \mathrm{l} / \mathrm{n}=\sum_{t}\right| \Delta \mathrm{S}_{\mathrm{i}} / \mathrm{n}$, where $\mathrm{S}_{\mathrm{i}}=$ is the share; $\mathrm{i}=1, \ldots . \mathrm{n}$ (industries); $\mathrm{n}$ is the number of industries, and II denotes absolute value. The values of ISC are $\delta(78-91)=6.30, \delta(91-2000)=9.41$, $\delta(1978-2000)=3.75$.

Table 1. Sources of industrial growth in the Malaysian Economy in the sub periods of 1978-1991, 1991-2000, and Overall Period 1978-2000

\begin{tabular}{|c|c|c|c|c|c|c|}
\hline \multirow[t]{3}{*}{ Sector } & \multicolumn{2}{|c|}{ Domestic Demand Export } & \multicolumn{2}{|c|}{ Import Substitution Import } & \multirow[t]{2}{*}{ Technological } & \multirow[t]{2}{*}{ Total } \\
\hline & & Demand & & Substitution & & \\
\hline & Expansion & Expansion & Final Goods & Intermediate Goods & Change & \\
\hline \multicolumn{7}{|l|}{$1978-1991$} \\
\hline \multirow[t]{2}{*}{ Agriculture } & 55.51 & 34.77 & -10.69 & -6.21 & 26.62 & 100 \\
\hline & 3.78 & 2.37 & -0.73 & -0.42 & 1.81 & 6.81 \\
\hline \multirow[t]{2}{*}{ Mining } & 64.76 & 53.04 & -12.05 & -5.56 & -0.19 & 100 \\
\hline & 2.18 & 1.79 & -0.41 & -0.19 & -0.01 & 3.37 \\
\hline \multirow[t]{2}{*}{ Light Industry } & 29.12 & 22.27 & -5.35 & -1.94 & 55.91 & 100 \\
\hline & 7.32 & 5.60 & -1.35 & -0.49 & 14.05 & 25.13 \\
\hline \multirow[t]{2}{*}{ Heavy Industry } & 60.70 & 48.98 & -9.76 & -3.05 & 3.12 & 100 \\
\hline & 20.99 & 16.94 & -3.37 & -1.05 & 1.08 & 34.58 \\
\hline \multirow[t]{2}{*}{ Services } & 96.59 & 21.97 & -16.28 & -6.41 & 4.13 & 100 \\
\hline & 29.08 & 6.62 & -4.90 & -1.93 & 1.24 & 30.11 \\
\hline Total & 63.35 & 33.30 & -10.76 & -4.08 & 18.18 & 100 \\
\hline \multicolumn{7}{|l|}{$1991-2000$} \\
\hline \multirow[t]{2}{*}{ Agriculture } & 67.87 & 25.44 & 20.97 & -59.46 & 45.18 & 100 \\
\hline & 1.14 & 0.43 & 0.35 & -1.00 & 0.76 & 1.68 \\
\hline \multirow[t]{2}{*}{ Mining } & 63.36 & 75.12 & 11.39 & -19.18 & -30.68 & 100 \\
\hline & 3.00 & 3.55 & 0.54 & -0.91 & -1.45 & 4.73 \\
\hline \multirow[t]{2}{*}{ Light Industry } & -35.04 & -31.77 & -7.56 & 8.56 & 165.81 & 100 \\
\hline & 3.58 & 3.25 & 0.77 & -0.88 & -16.96 & -10.23 \\
\hline \multirow[t]{2}{*}{ Heavy Industry } & 36.67 & 45.41 & 6.66 & -5.61 & 16.87 & 100 \\
\hline & 24.58 & 30.44 & 4.46 & -3.76 & 11.31 & 67.04 \\
\hline \multirow[t]{2}{*}{ Services } & 42.97 & 21.91 & 9.80 & -17.09 & 42.42 & 100 \\
\hline & 15.80 & 8.06 & 3.60 & -6.29 & 15.60 & 36.78 \\
\hline Total & 48.11 & 45.73 & 9.73 & -12.83 & 9.26 & 100 \\
\hline \multicolumn{7}{|l|}{$1978-2000$} \\
\hline \multirow[t]{2}{*}{ Agriculture } & 150.00 & 73.03 & -3.63 & -79.46 & -39.95 & 100 \\
\hline & 2.81 & 1.37 & -0.07 & -1.49 & -0.75 & 1.87 \\
\hline \multirow[t]{2}{*}{ Mining } & 61.18 & 62.80 & -1.35 & -17.01 & -5.62 & 100 \\
\hline & 4.15 & 4.26 & -0.09 & -1.15 & -0.38 & 6.79 \\
\hline \multirow[t]{2}{*}{ Light Industry } & 82.71 & 64.17 & -1.88 & -23.23 & -21.77 & 100 \\
\hline & 8.19 & 6.36 & -0.19 & -2.30 & -2.16 & 9.91 \\
\hline
\end{tabular}




\begin{tabular}{lllllll}
\hline \hline \multicolumn{2}{l}{ Heavy Industry 60.66} & 61.41 & -1.30 & -8.32 & -12.44 & 100 \\
\multirow{2}{*}{ Services } & 37.04 & 37.50 & -0.80 & -5.08 & -7.60 & 61.06 \\
& 143.99 & 54.54 & -3.20 & -42.15 & -53.18 & 100 \\
\multirow{2}{*}{ Total } & 29.33 & 11.11 & -0.65 & -8.59 & -10.83 & 20.37 \\
\hline \hline
\end{tabular}

Note: Entries in bold indicate contribution as percentage of total output growth.

Table 2. Gross output growth rate (\%)

\begin{tabular}{|c|c|c|c|c|c|c|c|c|c|}
\hline & & & & $\Delta 1978-19$ & & & & & \\
\hline & & $\Delta \mathrm{X} / \mathrm{X} 78$ & FDE & EDE & ISF & ISW & IOC & S78 & $\Delta \mathrm{X} / \mathrm{X} 91$ \\
\hline I & Agriculture (1-6) & 2173.95 & 1065.15 & 622.59 & -208.77 & -132.33 & 827.30 & 12.57 & 363.96 \\
\hline 1 & Others Agriculture & 268.60 & 200.83 & 59.14 & -38.40 & -16.09 & 63.12 & 2.59 & 103.66 \\
\hline 2 & Rubber Plantation & 70.61 & 44.38 & 19.25 & -13.95 & -22.66 & 43.59 & 1.93 & 118.41 \\
\hline 3 & Oil Palm & 741.51 & 39.02 & 49.04 & -12.90 & -24.14 & 690.49 & 1.27 & -62.15 \\
\hline 4 & Livestock & 290.48 & 258.65 & 76.39 & -46.86 & -24.16 & 26.45 & 1.47 & 60.99 \\
\hline 5 & Forestry & 664.06 & 358.42 & 393.45 & -61.52 & -30.58 & 4.28 & 2.82 & 16.69 \\
\hline 6 & Fishing & 138.69 & 163.85 & 25.32 & -35.15 & -14.70 & -0.63 & 2.48 & 126.36 \\
\hline II & Mining & & & & & & & & \\
\hline 7 & Petrol Mining & 350.79 & 227.16 & 186.06 & -42.28 & -19.51 & -0.65 & 6.24 & 378.84 \\
\hline III & Light Industry & 8796.57 & 4904.62 & 3396.00 & -858.08 & -266.16 & 1620.19 & 17.78 & 2070.99 \\
\hline 8 & Dairy Product & 206.29 & 235.69 & 47.61 & -45.50 & -10.06 & -21.45 & 1.19 & 132.23 \\
\hline 9 & Vegetable Fruit & 464.68 & 303.03 & 234.86 & -56.16 & -6.05 & -11.01 & 0.61 & 256.86 \\
\hline 10 & Oil \& Fats & 1921.73 & 110.83 & 116.66 & -26.43 & -17.82 & 1738.49 & 5.42 & -2227.62 \\
\hline 11 & Grain Mill & 52.11 & 56.61 & 22.70 & -19.37 & -9.78 & 1.95 & 1.45 & 146.61 \\
\hline 12 & Baker Conf & 566.87 & 472.62 & 188.90 & -80.26 & -4.70 & -9.68 & 0.64 & 158.26 \\
\hline 13 & Other Foods & 190.20 & 154.24 & 89.34 & -32.98 & -12.65 & -7.76 & 0.99 & 427.65 \\
\hline 14 & Animal Feed & 104.03 & 85.05 & 45.96 & -18.14 & -66.27 & 57.42 & 0.50 & -26.72 \\
\hline 15 & Beverages & 329.05 & 363.62 & 41.06 & -64.36 & -9.37 & -1.89 & 0.46 & 201.06 \\
\hline 16 & Tobacco & 242.67 & 267.70 & 12.98 & -51.21 & -3.78 & 16.99 & 0.79 & 254.22 \\
\hline 17 & Textiles & 559.79 & 385.55 & 355.25 & -65.67 & -14.51 & -100.83 & 1.57 & 268.82 \\
\hline 18 & Wearing & 1774.64 & 999.70 & 932.03 & -156.44 & -9.67 & 9.02 & 0.59 & 288.87 \\
\hline 19 & Sawmills & 704.07 & 421.68 & 427.95 & -71.34 & -15.60 & -58.61 & 2.53 & 294.93 \\
\hline 20 & Furniture Fixture & 1205.35 & 654.56 & 667.88 & -106.74 & -8.26 & -2.10 & 0.21 & 1515.88 \\
\hline 21 & Paper Printing & 475.09 & 393.75 & 212.81 & -63.49 & -77.62 & 9.64 & 0.84 & 379.94 \\
\hline IV & Heavy Industry & 18189.98 & 12242.51 & 7886.63 & -1922.95 & -881.30 & 865.09 & 21.35 & 8128.94 \\
\hline 22 & Industrial Chemical & 2956.79 & 1503.27 & 1586.75 & -222.74 & -76.82 & $\overline{166.33}$ & 0.64 & 390.20 \\
\hline 23 & Paints. Etc & 343.98 & 553.53 & 116.97 & -85.96 & -53.62 & -186.95 & 0.16 & 416.92 \\
\hline 24 & Other Chem. Product & 505.09 & 384.21 & 228.47 & -66.36 & -19.23 & $\begin{array}{l}-21.99 \\
\end{array}$ & 0.62 & 696.92 \\
\hline 25 & Petrol Product & 243.97 & 265.67 & 138.97 & -46.43 & -31.67 & -82.58 & 2.49 & 1050.63 \\
\hline 26 & Processed Rubber & 65.54 & 59.43 & 35.75 & -20.97 & -2.48 & -6.20 & 3.88 & -2.81 \\
\hline
\end{tabular}




\begin{tabular}{|c|c|c|c|c|c|c|c|c|c|}
\hline 27 & Rubber Product & 1146.84 & 785.52 & 565.85 & -123.74 & -24.45 & -56.33 & 0.81 & 194.43 \\
\hline 28 & Plastic Product & 1484.78 & 941.90 & 551.29 & -144.68 & -102.23 & 238.49 & 0.44 & 302.88 \\
\hline 29 & Glass Product & 818.89 & 571.64 & 375.21 & -90.47 & -72.29 & 34.81 & 0.34 & 399.75 \\
\hline 30 & Cement & 538.98 & 371.98 & 136.19 & -59.47 & -140.25 & 230.54 & 0.33 & -26.59 \\
\hline 31 & Non Metallic & 435.47 & 408.65 & 158.23 & -65.64 & -84.86 & 19.09 & 0.27 & 221.03 \\
\hline 32 & Basic Metal & 146.30 & 128.54 & 38.10 & -29.64 & -23.15 & 32.45 & 4.33 & 310.53 \\
\hline 33 & Other Metal & 534.86 & 450.25 & 208.90 & -72.68 & -31.00 & -20.61 & 0.69 & 774.50 \\
\hline 34 & Non Electrical Mach. & 1433.98 & 1530.50 & 140.85 & -229.80 & -68.33 & 60.74 & 0.90 & 1739.35 \\
\hline 35 & Elect .Mach & 4074.00 & 1918.05 & 2399.85 & -288.66 & -35.74 & 80.51 & 3.07 & 760.92 \\
\hline 36 & Motor Vehicles & 766.34 & 736.43 & 45.10 & -118.63 & -24.64 & 128.07 & 1.50 & 134.62 \\
\hline 37 & Other Transport & 912.99 & 648.25 & 113.86 & -104.50 & -70.87 & 326.25 & 0.41 & 93.68 \\
\hline 38 & Other Mfg Product & 1781.18 & 984.70 & 1046.30 & -152.59 & -19.69 & -77.54 & 0.49 & 671.97 \\
\hline V & Services & 921.49 & 979.57 & 133.16 & -163.84 & -43.52 & $\overline{16.11}$ & 42.06 & 350.63 \\
\hline 39 & Construction & 453.87 & 555.18 & 9.32 & -91.94 & -8.82 & -9.87 & 7.96 & 101.46 \\
\hline 40 & Others Services & 467.62 & 424.40 & 123.84 & -71.91 & -34.70 & 25.98 & 34.10 & 249.17 \\
\hline
\end{tabular}

Table 2. continued

$\Delta 1991-2000 \quad \Delta 1978-2000$

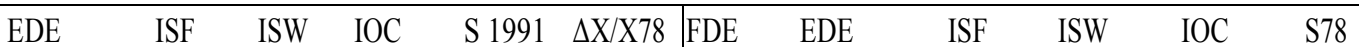

I

III

1

13

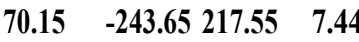

1491.33

$2471.46 \quad 1152.23$

(1-6)

Others $\quad 31.24$

Agriculture

Rubber $\quad 26.72$

Plantation

Oil Palm $\quad-13.57$

$\begin{array}{llll}-3.40 & -57.28 & 31.54 & 0.36\end{array}$

Livestock 12.01

$\begin{array}{lll}16.98 & -34.29 & 3.16\end{array}$

$11.15 \quad-38.66 \quad 9$.

Fishing $\quad 18.58$

22.

$43.13 \quad-72.68 \quad-116.25 \quad 3.56$

Petrol 284.59

Mining

Light Industry

1636.0

Dairy $\quad 18.76$

Product

Vegetable $\quad 126.41$

Fruit

Oil \& Fats $\quad-33.67$

Grain Mill 28.48

$\begin{array}{llll}15.05 & -43.37 & 100.11 & 0.38\end{array}$

$\begin{array}{llll}20.12 & -11.45 & 26.19 & 0.59\end{array}$

Baker Conf 55.96

Other

79.24 $\begin{array}{llll}-8.31 & 26.47 & -2177.70 & 2.5\end{array}$

14.50

$19.58 \quad-13.90 \quad 55.3$

$\begin{array}{llll}33.86 & -61.94 & 201.34 & 0.4\end{array}$
289.71

$394.65 \quad 197.02$

$13.79 \quad-27.97 \quad 47.23 \quad 1.39$

72

$-89.21$

$133.68 \quad 81.37$

433.55

$590.38 \quad 565.59 \quad 475.27$

2123.75

$1299.34 \quad 1333.71$

$\begin{array}{llll}50 & -30.88 & 95.13 & 0.65\end{array}$

229.84

$439.50 \quad 147.76$

1339.777

86.60

$-19.57$

$1342.64 \quad 996.04 \quad 558.01$

504.92

$785.70 \quad 344.50$ $\begin{array}{lll}-60.06 & -1379.68 & -692.63\end{array}$

12.57

$\begin{array}{llll}-3.91 & -137.47 & -162.87 & 1.93\end{array}$

\begin{tabular}{l|llllll}
-93.24 & 133.52 & 141.84 & -3.87 & -283.39 & -81.32 & 1.27
\end{tabular}

$\begin{array}{llll}-14.92 & -230.64 & -116.84 & 1.47\end{array}$

$\begin{array}{llll}-13.33 & -340.65 & -96.49 & 2.82\end{array}$

$\begin{array}{lllllll}360.13 & 601.32 & 103.49 & -14.34 & -232.26 & -98.08 & 2.48\end{array}$

$\mathbf{- 2 8 . 7 4} \quad \mathbf{- 3 6 1 . 1 5} \quad \mathbf{- 1 1 9 . 4 2} \quad 6.24$

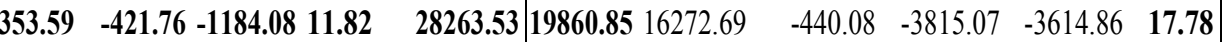

$-10.93 \quad-175.40 \quad-171.10 \quad 1.19$

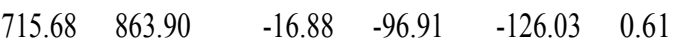

$\begin{array}{llll}-9.19 & -255.06 & -348.10 & 5.42\end{array}$

$\begin{array}{llll}-5.00 & -109.59 & -138.81 & 1.45\end{array}$

$\begin{array}{llll}-22.73 & -104.29 & -84.38 & 0.64\end{array}$ $\begin{array}{llll}-18.11 & -248.15 & -359.02 & 0.99\end{array}$ 


\section{Foods}

14

15

16

17

18

19

20

21

IV

22

23

24

25

26

27

28

29

30

31

32

33

34

36

37

38

V

39

Fixture

Paper

Heavy

Petrol

Rubber

Rubber

Plastic

Glass

Product

Non

Mach.

35
Animal Feed 5.64

Beverages 36.73

Tobacco $\quad 139.26$

Textiles

80.31

Wearing

106.29

Sawmills $\quad 135.17$

Furniture $\quad 761.72$

Printing

$\begin{array}{lllll}95.70 & 30.49 & -95.07 & 174.85 & 1.08\end{array}$

Industry

Industrial

Chemical

3324.10

Paints. Etc 209.69

Other Chem. 271.72

Product

265.33

Product

Processed 20.26

Product

96.57

Product

182.61

129.22

Cement

21.23

Non Metallic 32.20

Basic Metal 142.29

Other Metal 157.32

922.41

Electrical

Elect .Mach 360

Motor $\quad 27.01$

Vehicles

Other $\quad 71.17$

Transport

Other Mfg 272.5

Product

Services $\quad 68.84$

Construction 11.97 $\begin{array}{llll}17.31 & -20.03 & 55.04 & 2.52\end{array}$ $\begin{array}{llll}16.40 & -32.97 & -24.02 & 0.87\end{array}$

$\begin{array}{llll}43.64 & -28.24 & 150.31 & 0.84\end{array}$

$42.99 \quad-51.41 \quad 114.65 \quad 47.16$ $\begin{array}{llll}543.7 & -883.98 & 2290.03 & 30.02\end{array}$

$\begin{array}{llll}18.92 & -16.31 & 29.27 & 1.20\end{array}$

$\begin{array}{llll}8.90 & -70.10 & -13.32 & 0.38\end{array}$

$\begin{array}{llll}22.80 & -22.37 & 73.86 & 0.36\end{array}$

$\begin{array}{llll}25.40 & -3.82 & -11.96 & 0.49\end{array}$

$\begin{array}{llll}24.45 & -30.59 & 88.80 & 1.08\end{array}$

$\begin{array}{llll}28.98 & -10.07 & 34.65 & 1.08\end{array}$

$\begin{array}{llll}25.56 & -24.28 & 44.94 & 2.09\end{array}$

$\begin{array}{llll}92.21 & -30.37 & 123.73 & 0.26\end{array}$

$22.21 \quad-49.29 \quad 180.17 \quad 1.96$

$\begin{array}{llll}31.04 & -58.86 & 65.00 & 0.17\end{array}$

$\begin{array}{llll}39.46 & -66.52 & 240.10 & 0.52\end{array}$

$64.98 \quad-140.53 \quad 460.05 \quad 1.45$

$\begin{array}{llll}10.62 & -1.75 & -35.08 & 0.92\end{array}$

$18.92-16.31-29.27 \quad 1.20$

$\begin{array}{llll}32.17 & -27.10 & -59.36 & 1.20\end{array}$

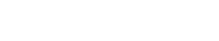

$\begin{array}{llll}23.40 & -67.79 & 195.65 & 0.57\end{array}$

$8.51 \quad-47.30 \quad-43.63 \quad 0.71$

$\begin{array}{llll}11.38 & -88.89 & 220.40 & 0.40\end{array}$

$\begin{array}{llll}22.91 & -53.33 & 88.18 & 2.22\end{array}$

$27.13 \quad-146.41 \quad 603.67 \quad 0.60$

$\begin{array}{llll}103.11 & -20.84 & 78.78 & 2.87\end{array}$

2.87

$-191.35$

\begin{tabular}{l|ll}
769.35 & 958.65 & 251.09
\end{tabular}

$1349.80 \quad 793.12 \quad 609.73$

$1794.40 \quad 1161.80 \quad 867.34$

\begin{tabular}{l|ll}
4718.65 & $2945.14 \quad 2304.69$
\end{tabular}

$2371.01 \quad 1308.11 \quad 1289.39$

\begin{tabular}{lll}
\hline \hline 12984.25 & 6573.49 & 7457.22
\end{tabular}

\begin{tabular}{l|ll} 
& & \\
\hline 983.21 & 2298.99 & 1087.49
\end{tabular}

\begin{tabular}{l|ll}
983.21 & 2298.99 & 1087.49 \\
& & \\
\hline
\end{tabular}

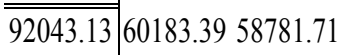

\begin{tabular}{lll}
\hline \hline 4972.19 & 4042.30 & 4790.70
\end{tabular}

\begin{tabular}{lll}
\hline \hline 4046.05 & $2503.01 \quad 2030.70$
\end{tabular}

\begin{tabular}{lll}
\hline \hline 2524.91 & 1933.84 & 1927.22
\end{tabular}

\begin{tabular}{l|ll} 
& & \\
\hline \hline 1892.01 & 2348.16 & 1342.64
\end{tabular}

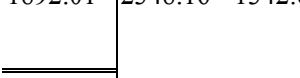

\begin{tabular}{l|ll}
\hline \hline 180.14 & 72.75 & 77.61
\end{tabular}

\begin{tabular}{l|ll}
\hline \hline 2918.24 & 1682.48 & 1629.71
\end{tabular}

\begin{tabular}{l|ll} 
& & \\
\hline 7181.10 & 4588.07 & 3737.93
\end{tabular}

\begin{tabular}{l|ll} 
& & \\
\hline \hline 1561.52 & 2233.61 & 1879.02
\end{tabular}

\begin{tabular}{l|ll} 
& & \\
\hline 309.28 & 952.36 & 433.74
\end{tabular}

\begin{tabular}{l|ll}
309.28 & 952.36 & 433.74 \\
\hline \hline-923.87 & 1043.23 & 525.56
\end{tabular}

\begin{tabular}{l|l|l|}
\hline \hline 824.50 & 673.77 & 648.43
\end{tabular}

\begin{tabular}{lll}
\hline \hline-882.88 & 1412.87 & 1082.93
\end{tabular}

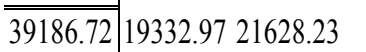

$\begin{array}{llll}-8.45 & -506.79 & -119.54 & 0.50\end{array}$

$\begin{array}{llll}-21.92 & -168.85 & -249.62 & 0.46\end{array}$

$\begin{array}{llll}-18.53 & -19.52 & -15.00 & 0.79\end{array}$

$\begin{array}{llll}-25.92 & -226.08 & 17.28 & 1.57\end{array}$

$\begin{array}{llll}-63.78 & -175.60 & -291.81 & 0.59\end{array}$

$\begin{array}{llll}-29.07 & -197.73 & 0.31 & 2.53\end{array}$

$\begin{array}{llll}-140.21 & -350.99 & -555.27 & \overline{12.1}\end{array}$

$\begin{array}{llll}-49.38 & -1180.11 & -1173.77 & \overline{0.84}\end{array}$

$-1289.96-11345.90-14286.11 \overline{\overline{21.35}}$

$\begin{array}{llll}-85.95 & -1451.03 & -2323.82 & \overline{0.64}\end{array}$

$\begin{array}{llll}-53.59 & -592.63 & 158.56 & \overline{0.16}\end{array}$

$\begin{array}{llll}-42.31 & -525.29 & -768.55 & \overline{0.62}\end{array}$

$\begin{array}{llll}-50.62 & -828.16 & -920.00 & \overline{2.49}\end{array}$

$\begin{array}{llll}-3.34 & -6.24 & 39.36 & \overline{\mathbf{3 . 8 8}}\end{array}$

$\begin{array}{llll}-36.93 & -261.51 & -95.50 & \overline{0.81}\end{array}$

$\begin{array}{llll}-97.88 & -659.90 & -387.13 & 0.44\end{array}$

$\begin{array}{llll}-48.19 & -1051.89 & -1451.03 & \overline{0.34}\end{array}$

$\begin{array}{llll}-20.89 & -865.83 & -190.10 & \overline{0.33}\end{array}$

$\begin{array}{lllll}-22.93 & -1210.13 & -1259.60 & \overline{0.27}\end{array}$

$\begin{array}{llll}-15.80 & -240.70 & -241.19 & \overline{4.33}\end{array}$

$\begin{array}{lllll}-30.87 & -1219.18 & -2128.63 & \overline{0.69}\end{array}$

$\begin{array}{llll}-408.40 & -597.13 & -768.95 & \overline{0.90}\end{array}$

\begin{tabular}{l|l}
\hline \hline 19399.52 & 10194.2811488 .18
\end{tabular}

$\begin{array}{llll}-216.38 & -568.25 & -1498.31 & \overline{3.07}\end{array}$ \begin{tabular}{l|llllll}
\hline \hline 674.35 & 1389.28 & 286.09 & -31.05 & -274.66 & -695.31 & $\overline{1.50}$
\end{tabular}

\begin{tabular}{l|ll}
\hline \hline 364.49 & 1241.08 & 677.95
\end{tabular}

$-27.72 \quad-518.81 \quad-1008.00 \quad \overline{\overline{0.41}}$

\begin{tabular}{l|llllll}
\hline \hline 7814.85 & 4539.33 & 4595.09 & -97.11 & -474.55 & -747.91 & 0.49
\end{tabular}

\begin{tabular}{l|ll}
\hline \hline 2638.06 & 722.98 & -58.82
\end{tabular}

$\begin{array}{llll}-549.19 & -620.18 & 2132.85 & \overline{42.06}\end{array}$

$\begin{array}{llll}21.05 & -6.39 & -0.77 \quad 8.57\end{array}$

\begin{tabular}{l|ll}
\hline 1249.79 & 113.11 & -28.03
\end{tabular}

$1260.29 \overline{7.96}$ 


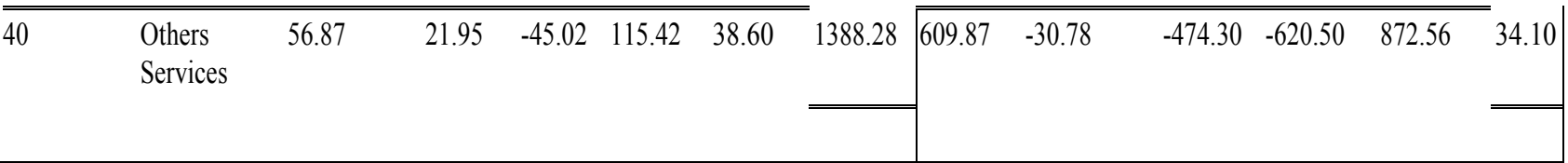

Note: $\quad \Delta \mathrm{X} / \mathrm{X}$ gross output growth rate; FDE-final demand expansion; EDE-export demand expansion; ISF - import substitution of final goods; ISW- import substitution of intermediate goods;IOC-IO coefficient change; S-gross output share.

Table 3. Change in gross output shares (percentage points)

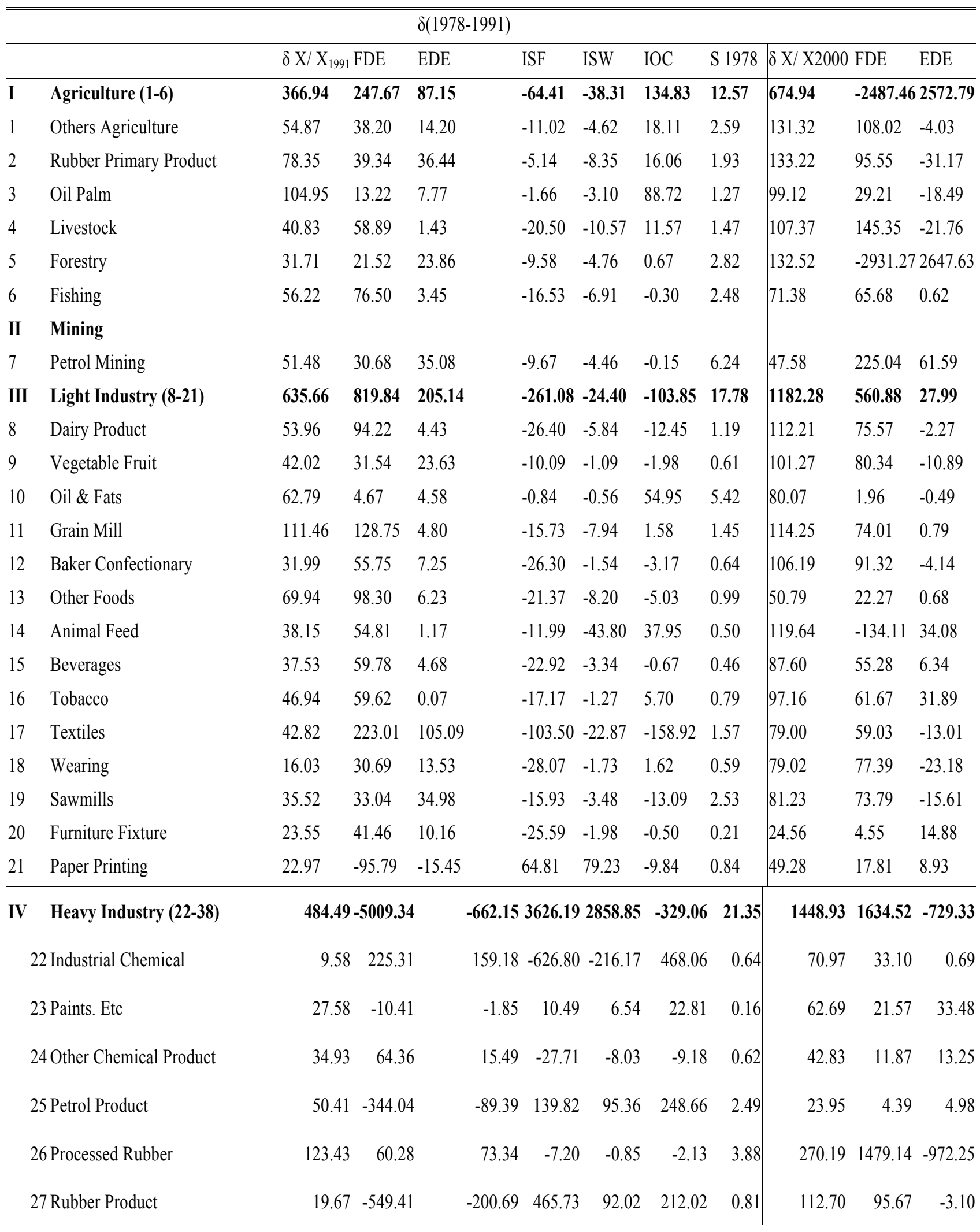




\begin{tabular}{|c|c|c|c|c|c|c|c|c|c|c|}
\hline 28 Plastic Product & 10.70 & 8.37 & 2.91 & -9.87 & -6.98 & 16.27 & 0.44 & 77.51 & 51.40 & 50.84 \\
\hline 29 Glass Product & \multicolumn{2}{|c|}{$17.41-4455.69$} & \multicolumn{4}{|c|}{$-609.743593 .832871 .70-1382.69$} & 0.34 & 59.42 & 18.07 & 13.98 \\
\hline 30 Cement & 13.73 & 8.73 & 1.70 & -6.37 & -15.02 & 24.69 & 0.33 & 164.35 & -392.32 & -14.76 \\
\hline 31 Non Metallic & 20.01 & -79.98 & -12.02 & 55.95 & 72.33 & -16.27 & 0.27 & 68.00 & 22.95 & 2.18 \\
\hline 32 Basic Metal & 57.23 & 29.32 & 31.71 & -5.54 & -4.32 & 6.06 & 4.33 & 87.20 & 39.20 & 27.85 \\
\hline 33 Other Metal & 33.71 & 179.98 & 59.98 & -120.60 & -51.45 & -34.20 & 0.69 & 35.08 & 6.90 & 2.19 \\
\hline 34 Non Electrical Machinery & 9.15 & -19.10 & -8.23 & 35.32 & 10.50 & -9.34 & 0.90 & 23.38 & 2.67 & 17.58 \\
\hline 35 Electrical Machinery & 8.20 & 16.71 & 16.14 & -29.17 & -3.61 & 8.14 & 3.07 & 46.37 & 16.53 & 17.58 \\
\hline 36 Motor Vehicles & 17.52 & 18.88 & 0.29 & -12.88 & -2.67 & 13.90 & 1.50 & 117.22 & 80.89 & 8.20 \\
\hline 37 Other Transport & 13.96 & 6.97 & 0.16 & -4.73 & -3.21 & 14.76 & 0.41 & 137.71 & 123.82 & 56.60 \\
\hline 38 Other Manufacture Product & 17.27 & -169.62 & -101.12 & 175.92 & 22.70 & 89.39 & 0.49 & 49.37 & 18.69 & 11.37 \\
\hline $\mathrm{V} \quad$ Services (39-40) & 53.24 & 130.13 & 3.00 & -68.06 & -15.94 & 4.10 & 42.06 & 192.09 & 139.70 & 14.12 \\
\hline 39 Construction & 27.29 & 79.23 & 0.67 & -43.72 & -4.19 & -4.69 & 7.96 & 114.96 & 100.62 & 5.79 \\
\hline 40 Others Services & 25.95 & 50.90 & 2.33 & -24.34 & -11.74 & 8.79 & 34.10 & 77.13 & 39.07 & 8.33 \\
\hline
\end{tabular}

Table 3 continued

\begin{tabular}{|c|c|c|c|c|c|c|c|c|c|c|}
\hline \multicolumn{5}{|c|}{$\overline{\delta(1991-2000)}$} & \multicolumn{4}{|c|}{$\delta(1978-2000)$} & \multirow[b]{2}{*}{ IOC } & \multirow[b]{2}{*}{ S1978 } \\
\hline$\overline{\text { ISF }}$ & ISW & IOC & S 1991 & $\delta \mathrm{X} / \mathrm{X} 2000$ & FDE & EDE & ISF & ISW & & \\
\hline-200.05 & 956.98 & -167.32 & 7.44 & 140.62 & -109.19 & -152.95 & 11.03 & 275.21 & 116.53 & 12.57 \\
\hline 11.41 & -23.14 & 39.07 & 1.39 & 24.93 & -16.24 & -4.83 & 1.48 & 23.65 & 20.88 & 2.59 \\
\hline 10.67 & -43.06 & 101.23 & 0.72 & 36.11 & -12.14 & 5.05 & 0.56 & 19.52 & 23.13 & 1.93 \\
\hline 10.31 & 173.75 & -95.67 & 0.36 & 35.99 & -10.95 & -2.06 & 0.51 & 37.68 & 10.81 & 1.27 \\
\hline 19.46 & -39.30 & 3.63 & 1.06 & 15.16 & -9.08 & -6.28 & 1.26 & 19.43 & 9.84 & 1.47 \\
\hline-263.27 & 912.81 & -233.38 & 2.61 & 14.54 & -51.41 & -143.31 & 6.19 & 158.24 & 44.82 & 2.82 \\
\hline 11.37 & -24.08 & 17.80 & 1.30 & 13.88 & -9.36 & -1.53 & 1.03 & 16.69 & 7.05 & 2.48 \\
\hline 70.72 & -119.17 & -190.60 & 3.56 & 8.47 & -3.03 & -2.84 & 0.81 & 10.17 & 3.36 & 6.24 \\
\hline 78.33 & 84.64 & 430.44 & 11.82 & 196.09 & -0.14 & 77.05 & -6.30 & 47.92 & 77.56 & 17.78 \\
\hline 7.17 & -15.26 & 47.01 & 0.65 & 20.95 & -14.80 & -4.94 & 1.24 & 19.97 & 19.48 & 1.19 \\
\hline 10.21 & -7.25 & 28.86 & 0.42 & 14.72 & 33.00 & 38.02 & -3.96 & -22.75 & -29.59 & 0.61 \\
\hline 0.30 & -0.96 & 79.26 & 2.54 & 17.40 & -4.49 & -1.38 & 0.35 & 9.69 & 13.23 & 5.42 \\
\hline 8.27 & -23.83 & 55.01 & 0.38 & 44.06 & -52.27 & -8.00 & 2.06 & 45.12 & 57.15 & 1.45 \\
\hline 10.98 & -6.25 & 14.29 & 0.59 & 11.75 & 15.78 & 20.46 & -2.63 & -12.08 & -9.77 & 0.64 \\
\hline 5.44 & -9.95 & 32.36 & 0.41 & 12.29 & -3.56 & -2.46 & 0.53 & 7.26 & 10.51 & 0.99 \\
\hline-26.25 & 206.66 & 39.26 & 0.38 & 15.79 & -2.00 & -1.36 & 0.26 & 15.29 & 3.61 & 0.50 \\
\hline 7.97 & -7.82 & 25.83 & 0.36 & 11.37 & -5.62 & -1.41 & 0.92 & 7.05 & 10.43 & 0.46 \\
\hline
\end{tabular}




\begin{tabular}{|c|c|c|c|c|c|c|c|c|c|c|c|c|}
\hline 9.52 & -1.43 & -4.48 & 0.49 & 15.78 & \multicolumn{2}{|c|}{21.99} & 1.99 & -2.86 & -3.01 & -2.32 & \multicolumn{2}{|c|}{0.79} \\
\hline 9.76 & -12.21 & 35.43 & 1.08 & 11.70 & & & 18.92 & -1.54 & -13.44 & 1.03 & 1.57 & \\
\hline 13.42 & -4.66 & 16.05 & 1.08 & 4.38 & & & 7.87 & -0.56 & -1.55 & -2.58 & 0.59 & \\
\hline 12.75 & -12.11 & 22.42 & 2.09 & 9.98 & & & 14.61 & -1.24 & -8.47 & 0.01 & 2.53 & \\
\hline 2.55 & -0.84 & 3.42 & 0.26 & 2.00 & & & -4.89 & 1.06 & 2.66 & 4.21 & 0.21 & \\
\hline 6.23 & -19.43 & 35.74 & 1.08 & 3.92 & & & -0.38 & 0.09 & 2.18 & 2.16 & 0.84 & \\
\hline 137.09 & 138.12 & 268.52 & 30.02 & & 199.81 & 176.90 & -97.34 & -2.24 & 36.28 & 86.22 & & 21.35 \\
\hline 5.39 & -11.97 & 43.77 & 1.96 & & 2.35 & -0.07 & -1.63 & 0.09 & 1.52 & 2.44 & & 0.64 \\
\hline 6.38 & -12.09 & 13.35 & 0.17 & & 5.98 & -1.31 & -2.09 & 1.03 & 11.41 & -3.05 & & 0.16 \\
\hline 3.28 & -5.53 & 19.96 & 0.52 & & 5.17 & -0.64 & -1.07 & 0.22 & 2.71 & 3.96 & & 0.62 \\
\hline 2.46 & -5.33 & 17.45 & 1.45 & & 4.18 & -0.24 & -0.32 & 0.13 & 2.18 & 2.42 & & 2.49 \\
\hline 95.94 & -15.82 & -316.82 & 0.92 & & 115.38 & 184.81 & -108.62 & -4.39 & -8.22 & 51.79 & & 3.88 \\
\hline 11.95 & -10.30 & 18.48 & 1.20 & & 7.67 & 3.46 & 15.87 & -1.09 & -7.74 & -2.83 & & 0.81 \\
\hline 14.65 & -12.34 & -27.04 & 1.20 & & 2.87 & -0.54 & -2.92 & 0.54 & 3.65 & 2.14 & & 0.44 \\
\hline 4.23 & -12.27 & 35.41 & 0.57 & & 3.58 & -0.15 & -0.63 & 0.08 & 1.80 & 2.48 & & 0.34 \\
\hline-58.96 & 327.91 & 302.47 & 0.71 & & 7.81 & -0.58 & -1.12 & 0.18 & 7.65 & 1.68 & & 0.33 \\
\hline 3.41 & -26.67 & 66.13 & 0.40 & & 4.71 & -0.16 & -0.31 & 0.05 & 2.51 & 2.62 & & 0.27 \\
\hline 7.99 & -18.60 & 30.76 & 2.22 & & 17.27 & -5.07 & 2.26 & 0.64 & 9.71 & 9.73 & & 4.33 \\
\hline 1.46 & -7.85 & 32.39 & 0.60 & & 4.09 & -0.11 & -0.25 & 0.04 & 1.61 & 2.81 & & 0.69 \\
\hline 2.00 & -0.40 & 1.53 & 2.87 & & 0.74 & -0.05 & -0.05 & 0.19 & 0.28 & 0.36 & & 0.90 \\
\hline 5.24 & -1.85 & 8.86 & 10.99 & & 1.32 & 1.08 & 18.91 & -1.77 & -4.65 & -12.26 & & 3.07 \\
\hline 9.31 & -10.77 & 29.60 & 2.52 & & 7.11 & -1.21 & -0.38 & 0.27 & 2.39 & 6.04 & & 1.50 \\
\hline 17.26 & -34.69 & -25.28 & 0.87 & & 6.65 & -0.62 & -0.56 & 0.14 & 2.62 & 5.08 & & 0.41 \\
\hline 5.09 & -3.29 & 17.52 & 0.84 & & 2.95 & -1.70 & -14.42 & 1.40 & 6.86 & 10.81 & & 0.49 \\
\hline 20.03 & -18.43 & 36.68 & 47.16 & & 17.78 & 35.86 & 1.42 & -7.49 & -16.95 & 4.94 & & 42.06 \\
\hline 12.97 & -3.94 & -0.47 & 8.57 & & 10.85 & 36.80 & 2.36 & -7.73 & -20.66 & 0.09 & & 7.96 \\
\hline 7.07 & -14.49 & 37.15 & 38.60 & & 6.93 & -0.94 & -0.94 & 0.24 & 3.71 & 4.85 & & 34.10 \\
\hline
\end{tabular}

Note: $\mathrm{X} / \mathrm{X}$ gross output share change; FDE-final demand expansion; EDE-export demand expansion; ISF - import substitution of final goods; ISW- import substitution of intermediate goods;IOC-IO coefficient change; S-gross output share. 